Astronuclear

Laboratory

WANL-TMI-1657

March 1966

\title{
A METHOD FOR APPROXIMATING EQUIVALENT CORROSION TIME FROM EXPERIMENTAL DATA
}

by

L. Wagner

Fluid Flow Laboratory
Approved by:

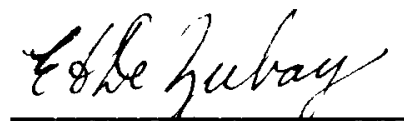

E. A. DieZubay, Manager

Fluid Flow Laboratory
INFORMATION CATEGORY

UNCLASSIFIED

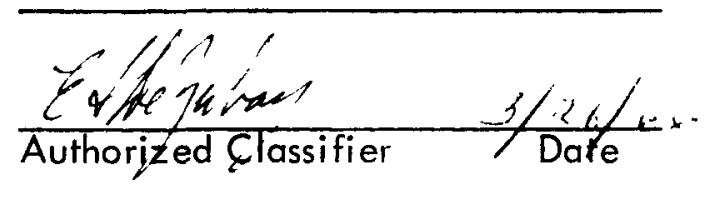

- NOTICE

This report was prepared as an account of work sponsored by the United States Government. Neither the United States nor the United States Energy their employees, nor any of their contractors, subcontractors, or their employees, makes any warranty, express or implied, or assumes any legal liability or responsibility for the accuracy, completeness or usefulness of any information, apparatus, product or process disclosed, or represents that its use would not process disclosed, or represents
infringe privately owned rights. 


\section{DISCLAIMER}

This report was prepared as an account of work sponsored by an agency of the United States Government. Neither the United States Government nor any agency Thereof, nor any of their employees, makes any warranty, express or implied, or assumes any legal liability or responsibility for the accuracy, completeness, or usefulness of any information, apparatus, product, or process disclosed, or represents that its use would not infringe privately owned rights. Reference herein to any specific commercial product, process, or service by trade name, trademark, manufacturer, or otherwise does not necessarily constitute or imply its endorsement, recommendation, or favoring by the United States Government or any agency thereof. The views and opinions of authors expressed herein do not necessarily state or reflect those of the United States Government or any agency thereof. 


\section{DISCLAIMER}

Portions of this document may be illegible in electronic image products. Images are produced from the best available original document. 


\section{A METHOD FOR APPROXIMATING EQUIVALENT CORROSION TIME FROM EXPERIMENTAL DATA}

In many development tests it becomes necessary to operate at conditions which can still be considered transient. Comparisons between tests at different test conditions resulting from modifications become difficult to interpret.

A FORTRAN program was written for a method of comparing equivalent corrosion time at a particular temperature level based on transient experimental temperature versus time data.

Assuming a rate reaction of graphite removal in the form of

$$
d m / d t=-C_{1} e^{-E / R T}
$$

where

$$
\begin{aligned}
& \mathrm{E}=\text { activation energy } \\
& \mathrm{R}=\text { gas constant } \\
& \mathrm{T}=\text { temperature } \\
& \mathrm{t}=\text { time } \\
& \mathrm{m}=\text { mass }
\end{aligned}
$$

a test of duration from $t=0$ to $t=$ to would produce

$$
M_{0}-m=\int_{M_{0}}^{m} d m=\int_{0}^{t_{0}} C_{1} e^{-E / R T} d t
$$

where

$$
T=f(t)
$$

The same weight loss would occur for a fixed reference temperature, $\mathrm{Tr}$, at a duration $\mathrm{tr}$ 


$$
C_{1} e^{-E / R T r} \cdot \operatorname{tr}=\int_{M_{0}}^{m} d m=\int_{0}^{t^{t o}} C_{1} e^{-E / R T} d t
$$

or

$$
\operatorname{tr}=e^{E / R T r} \int_{0}^{\text {to }} e^{-E / R T} \cdot d t
$$

or

$$
t r=\int_{0}^{t o} d t \cdot e^{\frac{E}{R}\left(\frac{1}{T r}-\frac{1}{T}\right)}
$$

where the reference temperature is $\mathrm{Tr}$ and the measured temperature is $\mathrm{T}$.

From graphite corrosion measurements, the best value at present of $E / R=B$ is:

$$
\frac{30,000 \mathrm{cal} / \mathrm{mole}}{1.987 \mathrm{cal} / \mathrm{mole}{ }^{\circ} \mathrm{K}}=15,100^{\circ} \mathrm{K}=27,200^{\circ} \mathrm{R}
$$

Therefore, the last equation can be rewritten in dimensionless form as

$$
r r / t o=\int_{0}^{t o / t o} d\left(t / t_{0}\right) \cdot e^{27,200\left(\frac{1}{T r}-\frac{1}{T}\right)}
$$

where

$$
\eta=\mathrm{t} / \mathrm{to}
$$

and if 


$$
\begin{aligned}
& Y=e^{27,200\left(\frac{1}{T r}-\frac{1}{F}\right)} \\
& t r / t o=\int_{0}^{1} Y d \eta=\bar{Y} \int_{0}^{1} d \eta=\bar{Y}
\end{aligned}
$$

Using Simpsons rule (Parabolic Rule) for an even number (2n) of spaces in the interval of $\eta=0$ and $\eta_{1}=1$ yields the approximation to the integration as

$$
\text { tr/to }=\bar{Y}=\frac{Y_{0}+4 Y_{1}+2 Y_{2}+4 Y_{3} \cdots \cdots 2 Y_{2 n-2}+4 Y_{2 n-1}+Y_{2 n}}{6 n}
$$

Hence, $n$ can be any convenient integer to insure that an even number of spaces $2 n$ exist between $\eta=0$ and $\eta=1$. The equivalent time tr at reference temperature $\operatorname{Tr}$ is then exactly equal to

$$
\operatorname{tr}=\bar{Y} \text { to }
$$

where to is the actual test time.

\section{DESCRIPTION OF INPUT DATA}

The following steps must be followed when inputting data:

1. Experimental temperature readings must be taken at equal time intervals, where the number of temperature readings must be odd.

2. The first card for each test series contains the following:

$$
\begin{array}{lll}
\mathrm{Tn} & =\text { Test number } & \text { Cols. } 1-12 \\
\mathrm{R} & =\text { Number of temperature readings (always odd) } & \text { Cols. } 13-24 \\
\text { Time } & =\text { Actual time of test period (min.) } & \text { Cols. } 25-36 \\
\text { Ref } & =\text { Reference temperature }\left({ }^{\circ} \mathrm{R}\right) & \text { Cols. } 37-48
\end{array}
$$


3. The next series of cards contain one temperature $\left({ }^{\circ} \mathrm{R}\right)$ reading per card,

There must be $R$ cards in each series.

4. Test number input format is an A field. All other input values must contain a decimal point.

\section{OUTPUT DATA}

The program was written to print out the following information:

Actual test time (min.)

Equivalent corrosion time (min.)

Given reference temperature $\left({ }^{\circ} R\right)$

List of input temperatures $\left({ }^{\circ} \mathrm{R}\right)$

A copy of the program and a sample of input and output data sheets follow. 
THIS PIROGRAM IS TH TFTEKMINE AN EQUIVELFNT CORRUSION TIME AI A

PRUPASEU TFMPERATURE. ASSUMING A RATP RFACTIUN OF GRAPAITF

RFMUVAL THE FULLUWING PRUGNAM WILL ATTEMPT TO SULVE INTEGRAL

BY USE UF SIMPSINS METHOU.

FLUID FLON LA

LAUPALEE MCCUNE

INPUT = TESI NO.,WO. UF IEMP REALINSS AT EQUAL INTERVALS,ACTUAL

TIME JF TEST, REFERENCF TEMP.

PRUGRAM NO. LHOIOO

DLMENSIUN T(100), Y (100)

1 READ( 5, 10O)TNS, R, TIME, RFF

100 FURMAT $(A 6,6 \times,(3 F 12.4))$
TO DETERMINE LENGTH OF SEGMFNT UNDER PARABOLA

$\mathrm{CUN}=(1.0 /(R-1.0)$

$\angle R E F=E \times P(27200 . / R E F)$

$N=R$

D) $5 \mathrm{I}=1$, N

$?$ PEAO(5, 1O1)T(1)

1) 1 FURMAT(F12.

$Y(I)=E X P(-77200 . / T(I))$

5 CONTINUF

$Z=Y(1)+Y(N)$

$\mathrm{M}=\mathrm{N}-1$

D) $7 \mathrm{~K}=2,4$,?

$Z=Z+4 . * Y(K)$

7 CONTINUE

$M M=V-2$

DO $\rightarrow K K=3, M, 2$

$Z=Z+2 * Y(K K)$

0 CUNTINUE

$F R=((C) N / 3) \div 7 * 2 \times E+)$

TREF = FP* TIME

WEITE $(6,1,4)$

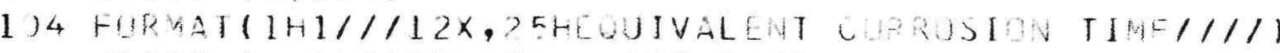

WDITE (S, IOP)TNU,TIME, PFF, TRFE

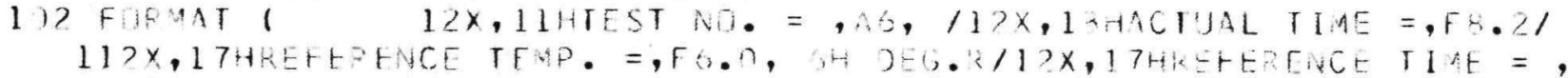
2F\&.?, $5 \mathrm{H}$ MIN./1/1 WRITE $(6,1) ?)$

108 FORAATI $15 x, 17$ HINPUI TEMFFRATUFE/1) NAITE $(6,1) 3)(T(I), I=1, N)$

103 FAFAAT (15x, 12.3$)$ (i) T 1 
FOUIVALTNT CURROSIUN TIAT

THST NHE $=1$.

ACTUAL TIME $=000$

REFEPENCE TEMP. $=4000$. UFG.R

REFEREUE TIMF $=5.25 \mathrm{MU}$.

INPUT TEMPFEATUEE

$$
\begin{aligned}
& 2100 \cdot 000 \\
& 2700 \cdot 000 \\
& 3000 \cdot 000 \\
& 4000 \cdot 000 \\
& 4500 \cdot 000 \\
& 4600 \cdot 000 \\
& 4300 \cdot 000 \\
& 4000 \cdot 000 \\
& 3400 \cdot 100 \\
& 2900 \cdot 00 \\
& 4109.100
\end{aligned}
$$




\section{SAMPLE INPUT}

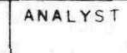

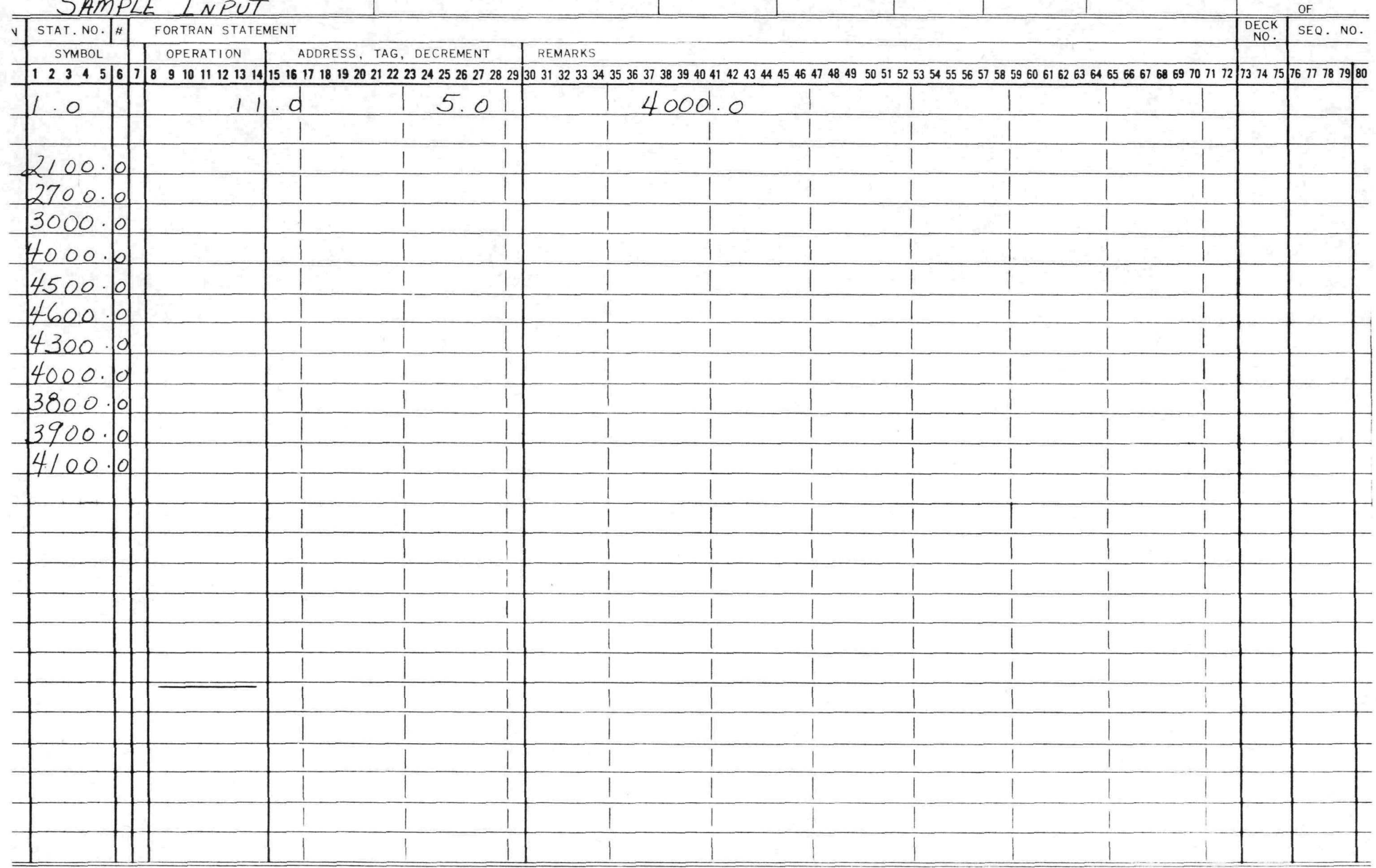

